\title{
Portfolio Rebalancing and the Turn-of-the-Year Effect
}

\author{
JAY R. RITTER and NAVIN CHOPRA*
}

\begin{abstract}
This paper finds that, for the 1935-1986 period, the market's risk-return relation does not have a January seasonal. The findings differ from those of other studies due to the use of value-weighted, rather than equally weighted, portfolios. Inferences are sensitive to the weighting procedure because of the small-firm return patterns in January. In particular, even in those Januaries for which the market return is negative, small-firm returns are positive, and they are more positive the higher is beta. This is consistent with the portfolio rebalancing explanation of the turn-of-the-year effect.
\end{abstract}

SINCE AT LEAST 1926, THE average return on small firms in January has been unusually high, a phenomenon known as the turn-of-the-year effect. In this paper, we present new evidence regarding the risk-return characteristics of small firms in January. We find that, for small firms, there is a positively sloped riskreturn relation in both up and down markets. This pattern is difficult to reconcile with the belief that the high return on small firms in January is equilibrium compensation for risk bearing.

We show how these patterns in small firms' returns have led others to conclude that the market's risk-return relation has a January seasonal. In particular, Rozeff and Kinney [21] and Tinic and West [22, 23], among others, using equally weighted portfolios formed on the basis of historical betas, have found a steeper slope for the CAPM's risk-return relation in January than in other months. We demonstrate that this pattern exists only for small firms. Consequently, statistical inferences about the risk-return relation are heavily dependent upon whether equally weighted or value-weighted portfolio returns are used in the estimation. We show that, for 1935-86, when monthly cross-sectional regressions are estimated using value-weighted portfolio returns, there is no more of a statistically significant difference in the estimated return to risk bearing in January than in the other eleven months of the year.

The notion that there is a January seasonal in the CAPM's risk-return relation for the U.S. has rapidly become accepted knowledge. For example, Corhay, Hawawini, and Michel [6] accept this conclusion and investigate whether other countries also have a seasonal in their risk-return relations. Cho and Taylor [4]

\footnotetext{
* Both authors from the School of Business Administration, University of Michigan. We would like to thank Cliff Ball, Robert S. Hansen, Robert Haugen (the referee), Greg Niehaus, Krishna Ramaswamy, Nejat Seyhun, René Stulz (the editor), and participants in workshops at the University of Michigan, the University of Pittsburgh, and the University of Wisconsin for useful comments. An earlier version of this paper was circulated under the title of "Risk, Return, and January." This research is partially supported by a Michigan Business School summer research grant.
} 
investigate the issue of seasonality in multifactor models. Our evidence indicates that this acceptance of a January seasonal in the CAPM's risk-return relation is premature.

We find that in January small firms outperform the market, irrespective of whether there is a positive or a negative return on the value-weighted market portfolio. Furthermore, high-beta small firms have greater excess returns than low-beta small firms in January, even when the market return is negative. We investigate three possible explanations for these findings: (i) the tax-loss-selling hypothesis, (ii) the risk-mismeasurement hypothesis, and (iii) the portfoliorebalancing hypothesis. To test the hypothesis that the positive relation between realized January small-firm returns and beta is due to tax-loss selling effects, we examine whether tax-loss selling status, as proxied by whether the prior year's return is positive or negative, is correlated with beta for small firms. We find that the necessary correlation is not present during 1935-1986. We also test whether high January returns on small firms can be attributed to an increase in the betas of small firms in January, as has been hypothesized by Rogalski and Tinic [19]. Our tests clearly reject this risk measurement explanation, for we find that the returns on small firms are positive in January, even when the return on the market portfolio is strongly negative.

As an alternative explanation for our findings, we examine the portfoliorebalancing hypothesis, developed by Haugen and Lakonishok [11, Chapter 4] and Ritter [18]. This hypothesis asserts that the high returns on risky securities in January are caused by systematic shifts in the portfolio holdings of investors at the turn of the year. In particular, institutional investors, following year-end "window dressing," become net buyers of risky securities at the turn of the year. Individual investors reinvest the proceeds from December's tax-motivated sales in January. The hypothesis asserts that this portfolio rebalancing produces the observed high January returns on small, risky stocks. The patterns in returns that we document are consistent with the portfolio-rebalancing hypothesis.

The remainder of the paper is structured as follows. In Section I, we describe our data and methodology. In Section II, we present our evidence on the seasonality of the risk-return relation. Causes for our finding that in January small firms have a positive relation between returns and betas, independent of the market return, are investigated in Section III. The paper concludes in Section IV with a summary of our results.

\section{Data and Methodology}

To examine the relation between realized returns and both systematic risk and size, we form portfolios of firms based upon independent rankings of beta and the market value of equity. Our motivation for forming portfolios is the same as the motivation in previous studies: because the beta estimates of individual firms are subject to substantial estimation error, an errors-in-the-variable bias would be present if individual securities were used.

For comparability with previous papers, we form portfolios using the same 
two-step procedure introduced by Fama and MacBeth [9]. ${ }^{1}$ Using the CRSP monthly returns file of NYSE securities, we calculate the betas of individual firms using ordinary least squares and the CRSP value-weighted index during a four-year portfolio formation period and use these ranked betas to form four portfolios containing an equal number of stocks. ${ }^{2}$ Because the beta of a portfolio is just the average beta of the securities comprising the portfolio, creating portfolios based upon their ranked betas maximizes the dispersion of portfolio betas across groups but subjects the measurement of the portfolio betas to order statistic bias. ${ }^{3}$ To avoid order statistic bias, we then recompute betas during a five-year portfolio estimation period. For both the portfolio formation period and the portfolio estimation period, only February-December returns are used. The purpose of excluding January returns from the beta calculations is to minimize the correlation of beta estimates and whatever omitted variable might be driving the turn-of-the-year effect. ${ }^{4}$ This consideration also motivates our use of the CRSP value-weighted index rather than the CRSP equally weighted index in the beta computations. For each subsequent year, the most recent prior nine years are used for the four-year portfolio formation period and the five-year portfolio estimation period. In each subsequent January, new firms are added to the sample. Firms are removed on a monthly basis as they are delisted during the year. Our testing period covers the fifty-two-year period 1935-1986. The number of firms in our portfolios during January varies from 326 in 1935 to 1049 in 1982, with the number of firms generally declining by approximately four percent by the subsequent December.

We also calculate the market value of each firm as of December 31 of each year from 1934 to 1985 by multiplying the price per share by the number of shares outstanding, and firms are then ranked by market values and divided into quintiles.

Based upon these two independent rankings, for each year firms are assigned to one of twenty portfolios. ${ }^{5}$ Table I reports the average beta and the average number of firms in each of the twenty portfolios formed on the basis of beta and

\footnotetext{
${ }^{1}$ The two-step procedure introduced by Fama and MacBeth [9] is subject to several criticisms on econometric grounds, as discussed by, among others, Hillion and Sirri [12]. Our use of the Fama and MacBeth methodology is motivated partially to facilitate comparison with other articles using the methodology (e.g., Tinic and West $[22,23]$ ) and partially because of criticisms of the power of multivariate tests, as discussed in MacKinley [16].

${ }^{2}$ Hillion and Sirri [12], among others, have noted that the return distributions of small firms are fat-tailed and skewed. Consequently, OLS estimates of beta are not of maximum efficiency. They find, however, that their qualitative conclusions regarding small-firm excess returns are not very sensitive to alternative estimation techniques.

${ }^{3}$ Because the measured betas equal the true beta plus a measurement error, high measured betas are likely to contain a positive measurement error and low measured betas are likely to contain a negative measurement error.

${ }^{4}$ Hillion and Sirri [12] and Rogalski and Tinic [19] present evidence that betas are higher for small firms in January than in other months. In Section III of the paper, we address whether higher betas for small firms in January can explain our findings, with negative results.

"The choice of beta quartiles and market value quintiles is based upon a tradeoff between a finer partitioning of the data and a desire to maintain a reasonably large number of firms in each portfolio, so that the portfolio return is not unduly influenced by firm-specific factors.
} 
Table I

\begin{tabular}{|c|c|c|c|c|c|}
\hline \multirow{2}{*}{$\begin{array}{c}\text { Market Value } \\
\text { Quintile }^{c}\end{array}$} & \multicolumn{4}{|c|}{ Beta Quartile } & \multirow{2}{*}{$\begin{array}{c}\text { Average } \\
\text { Beta }^{d}\end{array}$} \\
\hline & 1 (Low) & 2 & 3 & 4 (High) & \\
\hline \multirow[t]{2}{*}{ MV1 (Small) } & 0.940 & 1.162 & 1.314 & 1.529 & 1.236 \\
\hline & 34 & 34 & 37 & 51 & \\
\hline \multirow[t]{2}{*}{ MV2 } & 0.832 & 1.115 & 1.324 & 1.540 & 1.203 \\
\hline & 36 & 35 & 39 & 46 & \\
\hline \multirow[t]{2}{*}{ MV3 } & 0.822 & 1.107 & 1.288 & 1.519 & 1.184 \\
\hline & 37 & 38 & 41 & 40 & \\
\hline \multirow[t]{2}{*}{ MV4 } & 0.809 & 1.057 & 1.225 & 1.475 & 1.141 \\
\hline & 40 & 42 & 40 & 34 & \\
\hline \multirow{2}{*}{ MV5 (Large) } & 0.802 & 1.017 & 1.164 & 1.342 & 1.081 \\
\hline & 48 & 46 & 38 & 24 & \\
\hline Average Beta ${ }^{d}$ & 0.841 & 1.092 & 1.263 & 1.481 & \\
\hline
\end{tabular}

a Each average portfolio beta is computed as the equally weighted average of the values for the 572 non-January months in 19351986, as follows:

$$
\bar{\beta}_{p}=\frac{1}{572} \sum_{t=1}^{572}\left[\frac{1}{n_{t}} \sum_{i=1}^{n_{t}} \hat{\beta}_{i t}\right],
$$

where $n_{t}$ is the number of firms in portfolio $p$ in month $t$ and $\hat{\beta}_{i t}$ is the estimated individual firm beta, calculated using a two-step procedure for the previous nine calendar years, with January excluded. Betas are computed using February-December monthly returns and the CRSP value-weighted index with a four-year portfolio formation period and a five-year portfolio estimation period. For example, the beta quartiles for 1935 are formed based upon the ranked betas computed during the four-year portfolio formation period 1926-1929. The estimates are then computed during the fiveyear estimation period 1930-1934.

${ }^{b}$ The portfolios are formed based upon independent rankings of firms by beta and market value. Market values are computed on December 31 of the preceding year.

c The average market values of the market value quintiles are, respectively, $\$ 17$ million, $\$ 54$ million, $\$ 126$ million, $\$ 302$ million, and $\$ 1.61$ billion. These numbers are computed as the equally weighted average of the fifty-two yearly averages, where each yearly average is an equally weighted average of the market values of the firms in each quintile.

d The row and column averages are the equally weighted averages of the fifty-two yearly row and column averages, where each year's row and column averages are equally weighted across firms.

market value rankings. Because beta and firm size are negatively correlated, the twenty portfolios do not have an equal number of firms. As can be seen, small firms are more likely to have a high beta than are large firms. ${ }^{6}$ The betas tend to be greater than 1.0, which is a standard finding. This is because we are reporting equally weighted averages; the value-weighted averages would be closer to 1.0.

'In the 1980's, the negative correlation between firm size and beta is not present. Choi and Jen [5] also find this, using an equally weighted market index. 
There is reason, however, to believe that the betas of our portfolios suffer from some biases. In particular, Blume [1] has documented that there is a tendency for individual betas to move toward the mean over time. Consequently, the highbeta portfolios probably have slightly lower betas than our point estimates, and the low-beta portfolios probably have slightly higher betas. A second possible bias is that, due to leverage effects and other reasons, firms that have declined in value probably have had their betas increase. Since our small-firm portfolios have an above-average proportion of firms that have declined in value, it is possible that our procedure underestimates the true betas of the small-firm portfolios. When interpreting our results, these potential biases should be kept in mind.

\section{Evidence on the January Risk-Return Relation}

To analyze the relation between beta and realized security returns, holding size constant, we report the mean equally weighted returns on portfolios formed based upon beta quartiles and market value quintiles for the 1935-1986 period. Since previous evidence indicates that, for small firms, January returns are substantially different in their behavior from February-December returns (Keim [14] and Rogalski and Tinic [19]), we report the monthly average returns for these two periods separately throughout. Since this previous research also has found that returns in the non-January months are similar, we treat these eleven months as homogeneous.

Tables II and III report the average monthly returns for January and FebruaryDecember, respectively, for the twenty portfolios formed by ranking firms on both size and beta. Table II reports that there is a pronounced size effect for the month of January. In contrast, Table III reports that there is no systematic relation between realized returns and either beta or firm size during FebruaryDecember. For all twenty portfolios in Table III, the average returns are approximately one percent per month. These findings are consistent with those of other authors, e.g., Blume and Stambaugh [2] and Tinic and West [22].

The monthly average portfolio returns reported in Tables II and III are graphed in Figures 1 and 2, respectively. In Figure 1, the dramatic magnitude of the size effect in January is pictured. The contrast with Figure 2, where the monthly average portfolio returns for February-December are plotted, is apparent. For the largest firms, the January returns behave in a manner that is quite similar to the February-December returns. For the smallest firms, however, a positive relation between risk and return is displayed in January.

\section{A. Regression Results Using Equally Weighted Portfolios}

To examine the risk-return relation more carefully, for each size quintile we regress monthly equally weighted portfolio returns on a January intercept dummy variable, beta, and a cross-product term which produces a January slope dummy variable:

$$
r_{p t}=\gamma_{0}+\gamma_{1} D_{t}^{j a n}+\gamma_{2} \hat{\beta}_{p t}+\gamma_{3} \hat{\beta}_{p t} D_{t}^{j a n}+\varepsilon_{p t} .
$$


Table II

Average January Returns (1935-1986) for NYSE Firms Partitioned by Market Value Quintile and Beta Quartile ${ }^{a}$

\begin{tabular}{|c|c|c|c|c|c|}
\hline \multirow{2}{*}{$\begin{array}{c}\text { Market Value } \\
\text { Quintile }\end{array}$} & \multicolumn{4}{|c|}{ Beta Quartile } & \multirow[b]{2}{*}{$\mathrm{All}^{\mathrm{b}}$} \\
\hline & 1 (Low) & 2 & 3 & 4 (High) & \\
\hline \multirow[t]{2}{*}{ MV1 (Small) } & $0.0766^{c}$ & 0.0893 & 0961 & 0.1072 & 0.0949 \\
\hline & $(0.0135)^{d}$ & $(0.0165)$ & $(0.0162)$ & $(0.0165)$ & $(0.0155)$ \\
\hline \multirow[t]{2}{*}{ MV2 } & 0.0455 & 0.0469 & 0.0528 & 0.0600 & 0.0521 \\
\hline & $(0.0078)$ & $(0.0089)$ & $(0.0107)$ & $(0.0122)$ & $(0.0100)$ \\
\hline \multirow[t]{2}{*}{ MV3 } & 0.0332 & 0.0347 & 0.0330 & 0.0395 & 0.0354 \\
\hline & $(0.0071)$ & $(0.0087)$ & $(0.0096)$ & $(0.0114)$ & $(0.0090)$ \\
\hline \multirow[t]{2}{*}{ MV4 } & 0.0227 & 0.0216 & 0.0253 & 0.0221 & 0.0228 \\
\hline & $(0.0066)$ & $(0.0076)$ & $(0.0088)$ & $(0.0100)$ & $(0.0079)$ \\
\hline \multirow[t]{2}{*}{ MV5 (Large) } & 0.0159 & 0.0107 & 0.0084 & 0.0109 & 0.0120 \\
\hline & $(0.0056)$ & $(0.0064)$ & $(0.0075)$ & $(0.0083)$ & $(0.0064)$ \\
\hline $\mathrm{All}^{\mathrm{b}}$ & $\begin{array}{c}0.0361 \\
(0.0069)\end{array}$ & 0.0373 & 0.0429 & 0.0577 & \\
\hline & & & & & \\
\hline
\end{tabular}

a The average January return for portfolio $p$ is calculated as

$$
\bar{r}_{p}=\frac{1}{52} \sum_{t=1935}^{1986}\left[\frac{1}{n_{t}} \sum_{i=1}^{n_{t}} r_{i t}\right]
$$

where $r_{i t}$ is the return on security $i$ in month $t$ and $n_{t}$ is the number of securities in portfolio $p$ in month $t$.

b The returns in the "all" rows and columns are the equally weighted average returns over the fifty-two Januaries, where each January's return is the equally weighted average return of the firms in the appropriate row or column.

${ }^{c}$ A return of 0.0766 is 7.66 percent per month.

${ }^{d}$ Standard deviation of the means for the fifty-two portfolio returns are in parentheses.

\section{Table III}

Average Monthly Returns for February-December (1935-1986) for NYSE Firms Partitioned by Market Value Quintile and Beta Quartile ${ }^{\mathrm{a}}$

\begin{tabular}{lccccc}
\hline \multirow{2}{*}{$\begin{array}{c}\text { Market Value } \\
\text { Quintile }\end{array}$} & \multicolumn{5}{c}{ Beta Quartile } \\
\cline { 2 - 5 } MV1 (Small) & 0.0098 & 0.0112 & 0.0118 & 0.0105 & 0.0109 \\
& $(0.0026)$ & $(0.0033)$ & $(0.0033)$ & $(0.0039)$ & $(0.0035)$ \\
MV2 & 0.0099 & 0.0108 & 0.0116 & 0.0112 & 0.0109 \\
& $(0.0021)$ & $0.0024)$ & $(0.0029)$ & $(0.0034)$ & $(0.0027)$ \\
MV3 & 0.0099 & 0.0110 & 0.0114 & 0.0115 & 0.0110 \\
& $(0.0019)$ & $(0.0023)$ & $(0.0027)$ & $(0.0031)$ & $(0.0025)$ \\
MV4 & 0.0099 & 0.0103 & 0.0105 & 0.0116 & 0.0106 \\
& $(0.0017)$ & $(0.0022)$ & $(0.0025)$ & $(0.0028)$ & $(0.0023)$ \\
MV5 (Large) & 0.0091 & 0.0105 & 0.0102 & 0.0111 & 0.0102 \\
& $(0.0016)$ & $0.0020)$ & $(0.0022)$ & $(0.0027)$ & $(0.0022)$ \\
All & 0.0097 & 0.0108 & 0.0111 & 0.0112 & \\
& $(0.0020)$ & $(0.0025)$ & $(0.0027)$ & $(0.0032)$ \\
\hline
\end{tabular}

a The footnotes accompanying Table II are applicable to this table. 


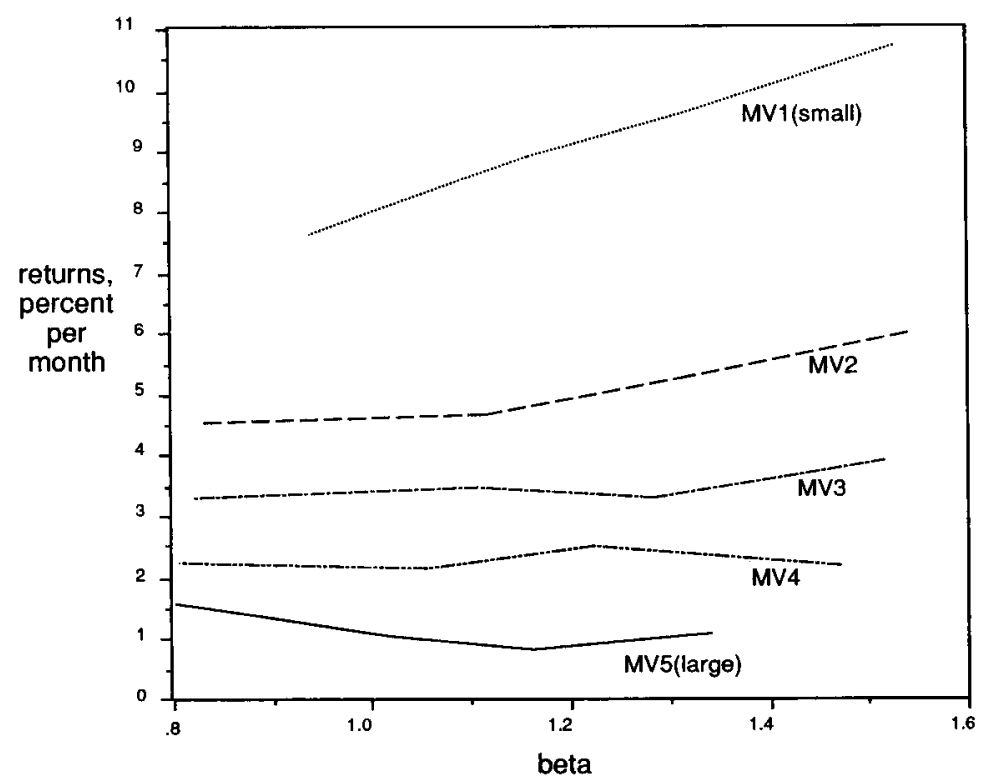

Figure 1. The relation between average realized January returns and beta for market value quintiles, 1935-1986. The points plotted are reported in Tables I (betas) and II (returns).

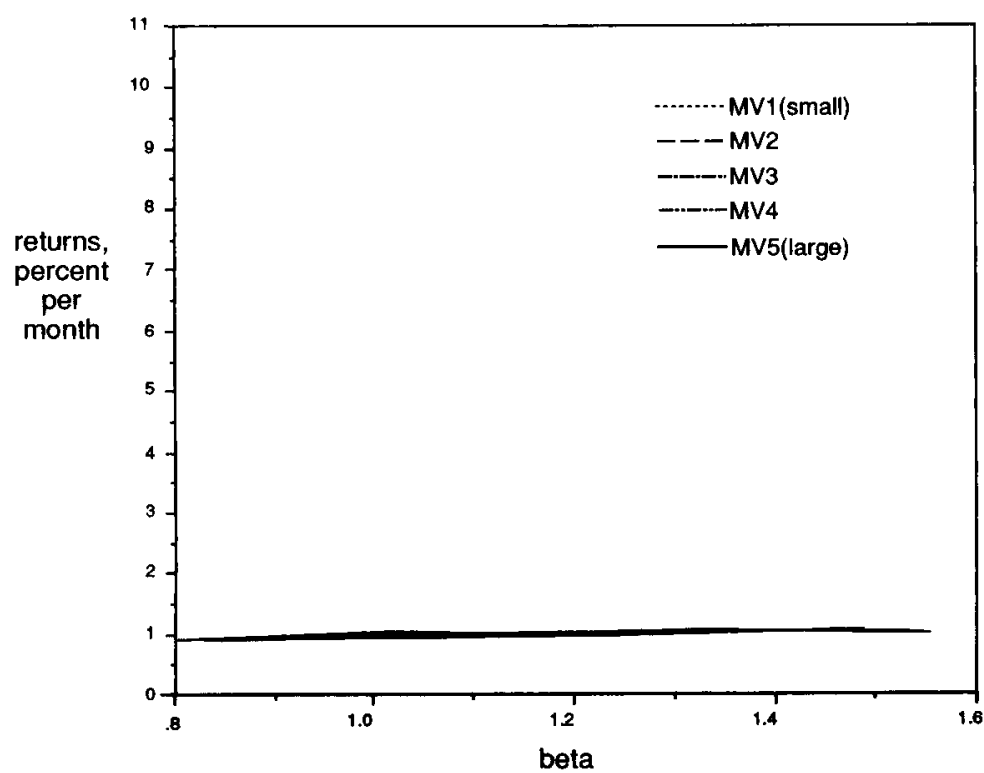

Figure 2. The relation between average realized February-December returns and beta for market value quintiles, 1935-1986. The points plotted are reported in Tables I (betas) and III (returns).

The January dummy variable, $D_{t}^{j a n}$, takes on the value of one in January and zero in other months. The equally weighted portfolio betas, $\hat{\beta}_{p t}$, have been estimated using the Fama and MacBeth [9] two-step procedure described previously. 
Rather than independently running the regressions using ordinary least squares (OLS) and then averaging the coefficients, as Fama and MacBeth do, we estimate pooled time-series cross-sectional regressions using Zellner's [25] seemingly unrelated regression (SUR) technique. The SUR technique takes into account the strong contemporaneous correlation of the portfolio returns. (For months in which stock returns are high, there is a tendency to have positive residuals for all twenty portfolios.)

The coefficient estimates for equation (1) are reported in Table IV, and they confirm the visual evidence presented in Figures 1 and 2: only for the two smallest firm quintiles is the January risk-return relation strongly positive. ${ }^{7}$ Indeed, for the two largest size quintiles, the sample January risk-return relation is actually negative, although insignificantly so, as can be seen by adding the coefficients on beta ( 0.00096 for the largest size quintile) and the cross-product term $(-0.01308$ for the largest size quintile).

The negative slopes for large firms in January result in a somewhat surprising phenomenon-the intercept terms are higher in January than in other months for all but the smallest quintile of firms-exactly the opposite result of studies that do not allow for a January seasonal in the slope of the risk-return relation. We do not attribute any special importance to the negative slopes and positive intercepts that we find for large firms in January. The bottom panels of Table IV report the results from estimating the parameters in the two twenty-six-year subperiods of 1935-1960 and 1961-1986. The results for each subperiod are qualitatively similar.

An important issue is raised by our Table IV finding that there is a statistically significant positive risk-return relation in January for small firms, but not for large firms: if a Fama and MacBeth [9]- or Tinic and West [22]-type regression were conducted using value-weighted portfolios rather than equally weighted portfolios, would the statistical inferences regarding the January risk-return relation be dramatically different? We now address this question. ${ }^{8}$

\section{B. Regression Results Using Value-Weighted Portfolios}

Unlike the procedure used in Tables II-IV, in which twenty portfolios are formed based upon independent rankings of beta and market value, in Table $\mathrm{V}$ we follow the Fama and MacBeth procedure of forming twenty portfolios based exclusively upon ranked betas. As in Tables II-IV, we continue to use the CRSP value-weighted index with February-December returns for calculating betas in both the portfolio formation period and the portfolio estimation period. We then use these betas, along with December 31 market values, to calculate value-

\footnotetext{
${ }^{7}$ The point estimates of the Table IV coefficients are generally qualitative similar to those obtained from OLS regressions. The standard errors of the coefficients are, however, generally about forty percent higher using OLS rather than SUR.

${ }^{8}$ In Tinic and West [23], the issue of whether the January risk-return relation is being driven by the behavior of small firms is addressed. Unfortunately, the methodology that Tinic and West adopt is not well suited for disentangling the effects of beta and size. Since beta and market value are negatively correlated, if portfolios are formed exclusively upon beta rankings and then the average market value of each portfolio is calculated, these two variables will be highly collinear when a grouped regression is run, as in Tinic and West [23].
} 
Table IV

Seemingly Unrelated Regression Results for Size Quintiles, with Portfolio Returns and Betas Computed Using Equal Weights $(1935-1986)^{\mathrm{a}}$

\begin{tabular}{|c|c|c|c|c|c|}
\hline \multirow[b]{2}{*}{ Size Portfolio } & \multicolumn{4}{|c|}{$\begin{array}{c}r_{p t}=\gamma_{0}+\gamma_{1} D_{t}^{j a n}+\gamma_{2} \hat{\beta}_{p t}+\gamma_{3} \hat{\beta}_{p t} D_{t}^{j a n}+\epsilon_{p t} \\
\text { Coefficient Estimates (Standard Errors in Parentheses) }\end{array}$} & \multirow[b]{2}{*}{$N$} \\
\hline & $\begin{array}{c}\text { Intercept } \\
\left(\gamma_{0}\right)\end{array}$ & $\begin{array}{l}\text { January } \\
\text { Dummy } \\
\left(\gamma_{t}\right)\end{array}$ & $\begin{array}{l}\text { Beta } \\
\left(\gamma_{2}\right)\end{array}$ & $\begin{array}{c}\text { Product of } \\
\text { Beta and } \\
\text { January Dummy } \\
\left(\gamma_{2} \times \gamma_{1}\right)\end{array}$ & \\
\hline \multicolumn{6}{|c|}{ January 1935 to December $1986^{\mathrm{b}}$} \\
\hline MV1 (Small) & $\begin{array}{r}0.00893^{*} \\
(0.00420)\end{array}$ & $\begin{array}{c}-0.00205 \\
(0.01447)\end{array}$ & $\begin{array}{c}0.00229 \\
(0.00307)\end{array}$ & $\begin{array}{c}0.06909^{*} \\
(0.01067)\end{array}$ & 2496 \\
\hline MV2 & $\begin{array}{r}0.01052^{*} \\
(0.00287)\end{array}$ & $\begin{array}{c}0.02090^{*} \\
(0.00995)\end{array}$ & $\begin{array}{c}0.00074 \\
(0.00209)\end{array}$ & $\begin{array}{c}0.01651^{*} \\
(0.00723)\end{array}$ & 2496 \\
\hline MV3 & $\begin{array}{r}0.01020^{*} \\
(0.00271)\end{array}$ & $\begin{array}{r}0.02537^{*} \\
(0.00941)\end{array}$ & $\begin{array}{c}0.00102 \\
(0.00200)\end{array}$ & $\begin{array}{c}-0.00079 \\
(0.00697)\end{array}$ & 2496 \\
\hline MV4 & $\begin{array}{r}0.01106^{*} \\
(0.00261)\end{array}$ & $\begin{array}{r}0.02119^{*} \\
(0.00906)\end{array}$ & $\begin{array}{c}-0.00013 \\
(0.00203)\end{array}$ & $\begin{array}{c}-0.00776 \\
(0.00705)\end{array}$ & 2496 \\
\hline MV5 (Large) & $\begin{array}{r}0.00940^{*} \\
(0.00286)\end{array}$ & $\begin{array}{c}0.01532 \\
(0.00991)\end{array}$ & $\begin{array}{c}0.00096 \\
(0.00245)\end{array}$ & $\begin{array}{c}-0.01308 \\
(0.00847)\end{array}$ & 2496 \\
\hline \multicolumn{6}{|c|}{ 1935-1960 Subperiod } \\
\hline MV1 (Small) & $\begin{array}{c}0.00246 \\
(0.00695)\end{array}$ & $\begin{array}{c}-0.00248 \\
(0.02410)\end{array}$ & $\begin{array}{c}0.00819 \\
(0.00463)\end{array}$ & $\begin{array}{r}0.06366^{*} \\
(0.01605)\end{array}$ & 1248 \\
\hline MV2 & $\begin{array}{c}0.00627 \\
(0.00436)\end{array}$ & $\begin{array}{c}0.01599 \\
(0.01507)\end{array}$ & $\begin{array}{c}0.00510 \\
(0.00290)\end{array}$ & $\begin{array}{c}0.01283 \\
(0.01001)\end{array}$ & 1248 \\
\hline MV3 & $\begin{array}{c}0.00721 \\
(0.00405)\end{array}$ & $\begin{array}{c}0.02512 \\
(0.01405)\end{array}$ & $\begin{array}{c}0.00465 \\
(0.00273)\end{array}$ & $\begin{array}{c}-0.00716 \\
(0.00949)\end{array}$ & 1248 \\
\hline MV4 & $\begin{array}{c}0.00816^{*} \\
(0.00381)\end{array}$ & $\begin{array}{c}0.02007 \\
(0.01324)\end{array}$ & $\begin{array}{c}0.00332 \\
(0.00270)\end{array}$ & $\begin{array}{c}-0.01294 \\
(0.00938)\end{array}$ & 1248 \\
\hline MV5 (Large) & $\begin{array}{c}0.00692 \\
(0.00382)\end{array}$ & $\begin{array}{c}0.01639 \\
(0.01320)\end{array}$ & $\begin{array}{c}0.00466 \\
(0.00299)\end{array}$ & $\begin{array}{c}-0.01770 \\
(0.01031)\end{array}$ & 1248 \\
\hline \multicolumn{6}{|c|}{ 1961-1986 Subperiod } \\
\hline MV1 (Small) & $\begin{array}{c}0.02367^{*} \\
(0.00493)\end{array}$ & $\begin{array}{c}0.01561 \\
(0.01716)\end{array}$ & $\begin{array}{r}-0.01217^{*} \\
(0.00407)\end{array}$ & $\begin{array}{c}0.06025^{*} \\
(0.01417)\end{array}$ & 1248 \\
\hline MV2 & $\begin{array}{c}0.01871^{*} \\
(0.00376)\end{array}$ & $\begin{array}{c}0.02896^{*} \\
(0.01311)\end{array}$ & $\begin{array}{r}-0.00779^{*} \\
(0.00303)\end{array}$ & $\begin{array}{c}0.01792 \\
(0.01057)\end{array}$ & 1248 \\
\hline MV3 & $\begin{array}{c}0.01645^{*} \\
(0.00367)\end{array}$ & $\begin{array}{c}0.02704^{*} \\
(0.01281)\end{array}$ & $\begin{array}{r}-0.00617^{*} \\
(0.00303)\end{array}$ & $\begin{array}{c}0.00531 \\
(0.01057)\end{array}$ & 1248 \\
\hline MV4 & $\begin{array}{c}0.01651^{*} \\
(0.00381)\end{array}$ & $\begin{array}{c}0.02333 \\
(0.01327)\end{array}$ & $\begin{array}{r}-0.00660 \\
(0.00333)\end{array}$ & $\begin{array}{r}-0.00267 \\
(0.01159)\end{array}$ & 1248 \\
\hline MV5 (Large) & $\begin{array}{c}0.01851^{*} \\
(0.00519)\end{array}$ & $\begin{array}{c}0.03001 \\
(0.01815)\end{array}$ & $\begin{array}{c}-0.00975 \\
(0.00494)\end{array}$ & $\begin{array}{c}-0.02338 \\
(0.01726)\end{array}$ & 1248 \\
\hline
\end{tabular}

* Coefficients with $t$-statistics greater than 2.00 in absolute value are marked with an asterisk.

"Portfolio returns, $r_{p t}$, are equally weighted averages of the individual monthly security returns. Portfolio betas, $\hat{\beta}_{p}$, are equally weighted averages computed using February-December monthly returns and the CRSP value-weighted index, with a four-year portfolio formation period and a five-year portfolio estimation period. The January dummy variable, $D_{t}{ }^{\text {jan }}$, takes on a value of one for January and a value of zero for other months.

"All five regressions in the top panel use fifty-two years of twelve monthly returns on four beta-segmented portfolios. 
Table V

Average Values of the Intercept and Slope

Coefficients of the Two-Parameter Model ${ }^{\mathrm{a}}$ $\left(t\right.$-Statistics in Parentheses $\left.{ }^{\mathrm{b}}\right)$

\begin{tabular}{|c|c|c|c|}
\hline \multicolumn{4}{|c|}{$r_{p t}=\gamma_{0 t}+\gamma_{t} \hat{\beta}_{p t}+\epsilon_{p t}$} \\
\hline Average Over & $\begin{array}{c}\text { Average } \\
\text { Intercept } \\
\text { Coefficient }\end{array}$ & $\begin{array}{l}\text { Averaze } \\
\text { Slope } \\
\text { Coefficient }\end{array}$ & $\begin{array}{c}\text { Sample } \\
\text { Size }\end{array}$ \\
\hline
\end{tabular}

Panel A (Current Study"): Portfolio Returns and Betas Computed Using Market Value Weights and the CRSP Value-Weighted Index for $1935-1986$

\begin{tabular}{|c|c|c|c|}
\hline January Only & $\begin{array}{c}0.001415 \\
(0.2301)\end{array}$ & $\begin{array}{c}0.012999 \\
(1.3383)\end{array}$ & 52 \\
\hline Rest of the Year & $\begin{array}{l}0.006323 \\
(3.5703)\end{array}$ & $\begin{array}{l}0.003278 \\
(1.5176)\end{array}$ & 572 \\
\hline All Months & $\begin{array}{c}0.005914 \\
(3.4754)\end{array}$ & $\begin{array}{l}0.004088 \\
(1.9113)\end{array}$ & 624 \\
\hline \multicolumn{4}{|c|}{$\begin{array}{c}\text { Panel B (Tinic and West }{ }^{\mathrm{d}} \text { ): Portfolio Returns and Betas } \\
\text { Computed Using Equal Weights and the CRSP Equally } \\
\text { Weighted Index for 1935-1982 }\end{array}$} \\
\hline January Only & $\begin{array}{l}-0.000645 \\
(-0.1443)\end{array}$ & $\begin{array}{c}0.047052 \\
(4.6335)\end{array}$ & 48 \\
\hline Rest of the Year & $\begin{array}{c}0.006689 \\
(4.0127)\end{array}$ & $\begin{array}{l}0.00381) 6 \\
(1.4145 i\end{array}$ & 528 \\
\hline All Months & $\begin{array}{c}0.006078 \\
(3.8635)\end{array}$ & $\begin{array}{l}0.0074: 10 \\
(2.7966)\end{array}$ & 576 \\
\hline
\end{tabular}

"For each month, $r_{p t}$ is the portfolio return on each of twenty beta-ranked portfolios and $\hat{\beta}_{p t}$ is the beta of each of these twenty portfolios, where $\hat{\beta}_{j,}$ is calculated using the Fama and MacBeth [9] two-step procedure. The $\epsilon_{j t}$ are zero-mean residıals. The monthly portfolio returns and betas are computed as

$$
r_{p t}=\sum_{i=1}^{n} w_{i t} r_{i t} \text { and } \hat{\beta}_{p t}=\sum_{i=1}^{n} w_{i t} \hat{\beta}_{i t},
$$

where $w_{i t}$ is the weight of firm $i$ in portfolio $p$ for month $t$. The weights, which sum to 1.0 for each portfolio, are market value weights in Panel A and equal weights $\left(1 / n_{1}\right)$ in Panel B.

" $t$-Statistics for both Panels A and B are computed as

$$
t \text {-statistic }=\frac{\bar{\gamma}_{i} \sqrt{\mathrm{T}}}{\mathrm{s}\left(\gamma_{u}\right)},
$$

where $\bar{\gamma}_{i}$ is the average value of $\gamma_{i t}$, for $\mathrm{i}=0$ or $1, \mathrm{~s}\left(\gamma_{i t}\right)$ is the timeseries standard deviation of $\gamma_{\mathrm{it}}$, estimated assuming normal, independent, and identically distributed random variables, and $T$ is the number of months of observations. For each morith, $\gamma_{01}$ and $\gamma_{11}$ are estimated using the twenty portfolio returns for that month.

'Betas have been computed using the Fama-MacBeth two-step procedure with a four-year portfolio formation period and a fiveyear estimation period, using February-December monthly returns only. For each month, twenty portfolios are formed based exclusively upon betas (unlike the other tables, where both beta and market value are used to form portfolios). Portfolio returns and betas are computed using market value (as of the prior December 31) weights within each portfolio. Each of the tventy portfolios is given an equal weight in the OLS regression performed for each month.

"From Table 4 of Tinic and West [22]. 
weighted portfolio returns and portfolio betas. ${ }^{9}$ This is in contrast to Tables IIIV, in which equally weighted portfolio returns and portfolio betas are used.

In Panel $\mathrm{A}$ of Table $\mathrm{V}$, we report the mean intercept and slope coefficients of monthly regressions with value-weighted portfolio returns as the dependent variable and value-weighted portfolio betas as the explanatory variable. These cross-sectional regressions have been run for each of the 624 months in the 19351986 period. We report the average intercept and slope coefficients for the fiftytwo Januaries, the 572 February-December months, and all 624 months in the sample. As can be seen, none of the $t$-statistics on the average slope coefficients is in excess of 2.00 . The highest average slope coefficient $t$-statistic is 1.91 , for the fifty-two-year period as a whole, which has an associated $p$-value of 0.028 in a one-tailed test.

It is worthwhile to compare our point estimates of the market's risk-return tradeoff with those of previous studies that use equally weighted portfolio returns. Panel B of 'Table V reproduces Tinic and West's [22] results for the 1935-1982 period, where betas have been computed using the CRSP equally weighted index and all twelve months of the year. The point estimates and $t$-statistics for the average slope coefficients of the non-January months are quite similar between Panels A and B, despite the use of different market indices, weighting schemes, and sample periods and whether January is included in beta estimation. Our average slope coefficient in Panel A is 0.003278 (implying an annualized 3.93 percent extra return per unit of systematic risk), while Tinic and West's average slope coefficient in Panel B is 0.003806 (implying an annualized 4.57 percent extra return per unit of systematic risk). ${ }^{10}$

The primary difference between the two panels is in January: our average slope coefficient is only 0.012999 , a full seventy-two percent lower than Tinic and West's average slope coefficient of 0.047052 . Part of the difference in these estimates is attributable to the use of the CRSP value-weighted index rather than the equally weighted index for computing betas, but most of the difference is attributable to using value-weighted portfolio returns rather than equally weighted portfolio returns. ${ }^{11}$

In Panel A of Table V, the average slope coefficients both for January and for the other eleven months of the year have $t$-statistics that are not statistically

\footnotetext{
"Robert Litzenberger and Krishna Ramaswamy, in work in progress, have also calculated market value-weighted portfolio returns and betas, achieving results similar to those reported here.

${ }^{10}$ For the year as a whole, our slope coefficient point estimate of $0.004088(t=1.91)$ for the 1935 1986 period is lower than those of other studies using equally weighted portfolio returns. Fama and MacBeth [9] report a point estimate of $0.008466(t=2.57)$ for the 1935-June 1968 period, while Tinic and West [22] report point estimates for 1935-1982 of $0.007410(t=2.80)$ using the CRSP equally weighted index and $0.005794(t=2.57)$ using the CRSP value-weighted index for computing betas. It should be noted that our slope coefficient estimated using value-weighted portfolio returns is lower than what is implied by the difference in returns on the market and Treasury bills. Ibbotson [13, Exhibit 8] reports that the average annual difference in returns between stocks and T-bills is 8.5 percent for the 1926-1987 period. Our monthly point estimate of 0.004088 implies a 4.91 percent annual difference.

${ }^{11}$ Tinic and West's estimate of 0.047052 is reduced to 0.030210 when the CRSP value-weighted index is used for computing betas and no other changes are made. Compare Tinic and West's [22] Table 7 (value-weighted index) with their Table 4 (equally weighted index). In additional work (unreported) done in preparing this paper, we found very minor changes due to our use of four more years or excluding January when computing betas using a value-weighted index.
} 
Table VI

Mean January Returns ${ }^{a}$ for the Small-Firm Quintile, Segmented by Prior Year's Returns and Beta Quartiles, 1935-1986 (Average Number of Firms in Parentheses)

\begin{tabular}{ccccc}
\hline & \multicolumn{4}{c}{ Beta Quartile } \\
\cline { 2 - 5 } Prior Year's Return & 1 (Low) & 2 & 3 & 4 (High) \\
\hline Negative or Zero Returns & $0.0976^{\prime \prime}$ & 0.1075 & 0.1173 & 0.1282 \\
in Prior Calendar Year & $(11)$ & $(12)$ & $(15)$ & $(20)$ \\
Positive Returns in Prior & 0.0618 & 0.0806 & 0.0742 & 0.0849 \\
Calendar Year & $(17)$ & $(21)$ & $(24)$ & $(31)$ \\
\hline
\end{tabular}

"Mean returns are calculated as the equally weighted average of the $n$ January portfolio returns for each of the eight cells, where $n$ is the number of Januaries in which at least one firm was in a cell.

"A return of 0.0976 corresponds to a 9.76 percent per month return.

significant at the five percent significance level. Furthermore, a formal test of the hypothesis that the average slope coefficients are the same across January and non-January months cannot reject the hypothesis of no difference at the ten percent significance level. ${ }^{12}$ This supports our assertion that the previous finding (e.g., Rozeff and Kinney [21] and Tinic and West [22]) of a January seasonal in the market's risk-return relation is merely a manifestation of the small-firm pattern in January.

\section{Further Examination of the January Seasonal for Small Firms}

Given the previous literature documenting the strong relation between tax-loss selling status and January returns for small firms (Reinganum [17] and Roll [20]), it is worth investigating the possibility that the strongly positive January risk-return relation for small firms reported in Table IV is merely a manifestation of tax-loss selling effects. This could occur if, among small firms, there were a strong correlation between tax-loss selling status and beta. In Table VI, we investigate this possibility by segmenting the firms in the small-firm portfolios by their prior calendar year's returns. The top row reports the average January returns on small firms that had zero or negative returns during the prior calendar year and presumably were tax-loss selling candidates, for at least some investors. The bottom row reports the average January returns on small firms that had positive returns during the prior year and consequently are less likely to have been tax-loss selling candidates. Also reported is the average number of firms in each classification.

For all four beta quartiles, the average January returns are higher for the stocks that had negative or zero returns during the prior year than for those

\footnotetext{
${ }^{12}$ The $t$-statistic for a test of the hypothesis that the slope coefficients of 0.012999 for January and 0.003278 for the other eleven months are drawn from a distribution with a common mean is 1.257 , which has a one-tailed $p$-value of 0.105 .
} 
stocks that realized positive returns, consistent with Reinganum's [17] evidence. For both rows, however, there is a strong positive relation between beta and realized January returns. Furthermore, the number of firms in each beta quartile is divided between the prior year's losers and winners in a ratio of about two to three. Consequently, the necessary correlation between beta and tax-loss selling status is not present. Our interpretation is that the positive risk-return relation for small firms in January is not merely proxying for the tax-loss selling effect.

It should be noted, however, that tax-loss selling effects may not have been fully discerned by our simple measure. For example, Chan [3] and DeBondt and Thaler [7] have found that effects appear to persist in January at least five years after a loss is incurred. Zarowin [24] finds that these effects appear to be limited to January rather than spread throughout the year.

A second hypothesis that has been advanced to explain the high returns on small firms in January is the risk-mismeasurment hypothesis. This asserts that there is a January seasonal in the sensitivity of small firms to market risk, with the betas of small firms being higher in January than in February-December. ${ }^{13}$ A testable implication is that the excess return on small firms in January, calculated using February-December betas, is overestimated when the market return is high and is underestimated when the market return is low. We test this implication below.

A third hypothesis is the portfolio-rebalancing hypothesis of Haugen and Lakonishok [11] and Ritter [18]. Haugen and Lakonishok argue that money managers engage in "window dressing"; that is, they rebalance their portfolios prior to year end to remove securities which might be embarrassing if they appeared on year-end balance sheets. As soon as December 31 passes, these money managers again rebalance their portfolios, investing in more speculative securities including high-risk small firms.

Haugen and Lakonishok's hypothesis regarding the effects of seasonal portfolio rebalancing by institutional investors complements Ritter's [18] hypothesis regarding the effects of seasonal portfolio rebalancing by individuals. Ritter presents evidence that the buy/sell ratio of individual investors is below normal in December and above normal in January. ${ }^{14}$ Given that for every seller there must be a buyer, specialists and market makers presumably experience an inventory surge in December that accommodates this pattern. Both Haugen and Lakonishok and Ritter hypothesize that the turn-of-the-year effect is caused by a shift

\footnotetext{
${ }^{13}$ In their Table 3, Hillion and Sirri [12] find that, using the value-weighted market index, for the three smallest of their twenty portfolios of AMEX-NYSE stocks, the average January beta is 1.86 , as contrasted with a February-December value of 1.17. For comparison, the average FebruaryDecember beta for our smallest quintile of NYSE stocks is 1.236, as reported in Table I. Rogalski and Tinic [19] also find higher betas on small firms in January, using daily data and an equally weighted market index. It should be noted that no one has provided a plausible reason for why there should be a January seasonal in small-firm betas.

${ }^{14}$ Dyl [8] documents that the trading volume of individual stocks in both December and January is related to prior year returns, with "losers" having abnormally high December volume and "winners" having abnormally high January volume. Ferris, Haugen, and Makhija [10] provide evidence of a "disposition" effect among low capitalization stocks in which abnormal volume is positive for stocks that have appreciated and negative for stocks that have depreciated. They also find that there are strong turn-of-the-year patterns, consistent with Dyl's evidence.
} 
in demand from low-risk securities (cash and large company stocks) to high-risk securities (small stocks and higher risk securities, such as "junk" bonds), with this demand shift resulting in high returns on risky securities in January. This portfolio-rebalancing hypothesis has the testable implication that higher risk securities should outperform the market in January, irrespective of whether the market return is positive or negative. Before presenting our empirical results, it should be noted that it is not obvious what the appropriate measure of risk is since the portfolio-rebalancing hypothesis is based upon behavioral patterns rather than an equilibrium model. We continue to use beta as a measure of risk to facilitate a comparison of the alternative hypotheses.

To test both the portfolio-rebalancing and risk-mismeasurement hypotheses, we restrict our attention to the smallest quintile of NYSE firms. Within this quintile, we form beta quartile portfolios each year, using the same two-step procedure for calculating betas that we have used throughout the paper. Because we are forming beta quartile portfolios for small firms only, in each year there is an equal number of firms in each portfolio. This is in contrast with the portfolios used in Tables II-IV, where independent rankings of firms based upon both beta and market value result in portfolios of unequal size each year. As in Tables IIIV, the portfolio betas and returns are calculated on an equally weighted basis.

In Table VII, we present evidence bearing on both the portfolio-rebalancing and risk-mismeasurement hypotheses by reporting results conditional upon the realized January value-weighted market return. Panel A of Table VII reports the average raw January returns on the small-firm beta quartile portfolios. For the fifty-two years in 1935-1986, the top row reports the average portfolio returns in the thirteen Januaries with the highest realized market returns. The fourth row reports the average portfolio returns in the thirteen Januaries with the steepest market declines. We find that, even in the years when the market drops in January, the average return on the portfolios of small firms is positive, whether the portfolio betas are high or low. For the years in which the market significantly advances in January, all small-firm portfolios have high average returns, with the high-beta portfolio having the highest average returns.

In Panel B of Table VII, we report the excess returns, defined for each portfolio as

$$
e_{p t}=\left(r_{p t}-r_{f t}\right)-\hat{\beta}_{p t}\left(r_{m t}-r_{f t}\right),
$$

where $r_{p t}$ is the return in January $t$ on portfolio $p, r_{f t}$ is the risk-free rate of interest, measured as the monthly yield on three-month T-bills (from the CRSP government bond file), $r_{m t}$ is the CRSP value-weighted market return, and $\hat{\beta}_{p t}$ is the portfolio beta, estimated over the prior five years (excluding Januaries). The same patterns are present in the excess returns as are present in the raw returns.

The risk-mismeasurement hypothesis predicts that, if the true betas in January are higher than the February-December betas, when the market return is lower than the risk-free rate, excess returns computed using February-December betas should be negative for small firms. As can be seen from inspection of the bottom row of Panel B, the data clearly reject the hypothesis that underestimated betas are causing the patterns.

In Panel C of Table VII, we test the hypothesis that, for each quartile of realized January market returns, there is a positive relation between beta and 
Table VII

Mean January Returns and Excess Returns for Equally Weighted Small-Firm ${ }^{a}$ Portfolios Formed with an Equal Number of Firms in Each Beta Quartile, Segmented by the Realized Contemporaneous Value-Weighted Market Return, 1935-1986

\begin{tabular}{|c|c|c|c|c|}
\hline \multirow{2}{*}{$\begin{array}{c}\text { Realized January } \\
\text { Value-Weighted Market } \\
\text { Return Quartile }\end{array}$} & \multicolumn{4}{|c|}{ Beta Quartile } \\
\hline & 1 (Low) & 2 & 3 & 4 (High) \\
\hline \multicolumn{5}{|c|}{ Panel A: Raw Returns (Standard Deviation of Means) } \\
\hline & $\begin{array}{r}0.166^{c} \\
(0.037)\end{array}$ & $\begin{array}{c}0.182 \\
(0.034)\end{array}$ & $\begin{array}{c}0.201 \\
(0.036)\end{array}$ & $\begin{array}{c}0.227 \\
(0.033)\end{array}$ \\
\hline $0.049-0.010$ & $\begin{array}{c}0.077 \\
(0.012)\end{array}$ & $\begin{array}{c}0.094 \\
(0.015)\end{array}$ & $\begin{array}{c}0.100 \\
(0.013)\end{array}$ & $\begin{array}{c}0.109 \\
(0.016)\end{array}$ \\
\hline $0.009-(0.026)$ & $\begin{array}{c}0.072 \\
(0.034)\end{array}$ & $\begin{array}{c}0.069 \\
(0.042)\end{array}$ & $\begin{array}{c}0.081 \\
(0.038)\end{array}$ & $\begin{array}{c}0.062 \\
(0.031)\end{array}$ \\
\hline$(0.027)-(0.076)$ & $\begin{array}{c}0.012 \\
(0.010)\end{array}$ & $\begin{array}{c}0.021 \\
(0.011)\end{array}$ & $\begin{array}{c}0.026 \\
(0.018)\end{array}$ & $\begin{array}{c}0.022 \\
(0.013)\end{array}$ \\
\hline \multicolumn{5}{|c|}{ Panel B: Excess Returns ${ }^{d}$ (Standard Deviation of Means) } \\
\hline $0.135-0.050$ & $\begin{array}{c}0.097 \\
(0.031)\end{array}$ & $\begin{array}{c}0.100 \\
(0.026)\end{array}$ & $\begin{array}{c}0.104 \\
(0.029)\end{array}$ & $\begin{array}{c}0.120 \\
(0.027)\end{array}$ \\
\hline $0.049-0.010$ & $\begin{array}{c}0.050 \\
(0.010)\end{array}$ & $\begin{array}{c}0.061 \\
(0.012)\end{array}$ & $\begin{array}{c}0.062 \\
(0.011)\end{array}$ & $\begin{array}{c}0.068 \\
(0.014)\end{array}$ \\
\hline $0.009-(0.026)$ & $\begin{array}{c}0.076 \\
(0.032)\end{array}$ & $\begin{array}{c}0.076 \\
(0.040)\end{array}$ & $\begin{array}{c}0.089 \\
(0.036)\end{array}$ & $\begin{array}{c}0.071 \\
(0.029)\end{array}$ \\
\hline$(0.027)-(0.076)$ & $\begin{array}{c}0.055 \\
(0.010)\end{array}$ & $\begin{array}{c}0.073 \\
(0.010)\end{array}$ & $\begin{array}{c}0.084 \\
(0.019)\end{array}$ & $\begin{array}{c}0.088 \\
(0.012)\end{array}$ \\
\hline \multicolumn{5}{|c|}{$\begin{array}{l}\text { Panel C: Regression of Excess Returns on Portfolio Betas } \\
\qquad e_{p t}=a_{0}+a_{1} \hat{\beta}_{p t}+\epsilon_{p t}\end{array}$} \\
\hline & $\begin{array}{l}\text { Intercept } \\
(t \text {-Statistic })\end{array}$ & $\begin{array}{c}\text { Slope } \\
(t-\text { Statistic })\end{array}$ & $R_{\text {adjusted }}^{2}$ & $N$ \\
\hline $0.135-0.050$ & $\begin{array}{l}0.0153 \\
(0.33)\end{array}$ & $\begin{array}{l}0.0734 \\
(2.05)\end{array}$ & 0.059 & 52 \\
\hline $0.049-0.010$ & $\begin{array}{l}0.0427 \\
(2.03)\end{array}$ & $\begin{array}{l}0.0128 \\
(0.86)\end{array}$ & -0.005 & 52 \\
\hline $0.009-(0.026)$ & $\begin{array}{l}-0.0646 \\
(-1.17)\end{array}$ & $\begin{array}{l}0.1070 \\
(2.69)\end{array}$ & 0.109 & 52 \\
\hline$(0.027)-(0.076)$ & $\begin{array}{l}0.0122 \\
(0.63)\end{array}$ & $\begin{array}{l}0.0524 \\
(3.45)\end{array}$ & 0.176 & 52 \\
\hline
\end{tabular}

"Portfolios are formed from the smallest quintile of NYSE firms, measured on December 31 of each preceding year. Size is measured as market capitalization of common equity.

b Each of the four January market return quartiles includes thirteen Januaries in the 1935-1986 period. The quartile boundaries are, respectively, 5.0 percent, 1.0 percent, and minus 2.6 percent for the monthly returns. Negative market returns are in parentheses. The highest and lowest January market returns are 13.5 percent and minus 7.6 percent, respectively.

${ }^{c} A$ return of 0.166 corresponds to a 16.6 percent per month return.

${ }^{d}$ Excess returns are calculated as

$$
e_{p t}=\left(r_{p t}-r_{f t}\right)-\hat{\beta}_{p t}\left(r_{m t}-r_{f t}\right) .
$$

e These pooled time-series cross-section regressions each use fifty-two observations of four beta quartile portfolio returns in each of the thirteen Januaries. 
excess returns. The portfolio-rebalancing hypothesis predicts positive slope coefficients. For all four realized market return quartiles, the slope coefficients are positive, three of them significantly so. We interpret this evidence as supporting the portfolio rebalancing explanation of the turn-of-the-year effect.

A caveat is in order regarding the Panel $\mathrm{C}$ regressions. Because the excess returns used as the dependent variable are defined in equation (2) using the estimated $\hat{\beta}_{p t}$ values, it is possible that measurement errors could result in a spurious relation when $\hat{\beta}_{p t}$ is used as the explanatory variable in the Panel $\mathrm{C}$ regressions. Hence, these results should be viewed as only suggestive.

As noted earlier in this section, the appropriate definition of risk is not obvious for the portfolio-rebalancing hypothesis. Consequently, we have also formed small-firm portfolios based upon unique risk rankings. Although we do not report the results here due to space limitations, the qualitative patterns are similar to those in Table VII.

One aspect of our results is not consistent with beta being a sufficient measure of risk. In our Table IV SUR regressions, we do not find a positive risk-return relation for large firms in January. Only for the two smallest quintiles of firm size is the slope coefficient of the risk-return relation more positive in January than in other months. Perhaps large high-beta firms (such as Digital Equipment Corporation) are not the type of firms for which window dressing is appropriate.

\section{Conclusions}

For the 1935-1986 period, our point estimate of the market's risk-return relation is 0.004088 per month (4.91 percent on an annualized basis), with a $t$-statistic of 1.91 (one-tailed $p$-value of 0.028 ). Using value-weighted portfolio returns, we are unable to reject, at conventional significance levels, the hypothesis that the slope of the market's risk-return relation is the same in January as it is in the other eleven months of the year. This finding is at odds with other studies (e.g., Rozeff and Kinney [21] and Tinic and West [22]) using equally weighted portfolio returns. We attribute the difference in findings to the effects of the high January returns of small firms, the negative correlation between beta and market value, and the positive relation for small firms in January between beta and mean returns.

When we investigate why there is a positive risk-return relation in January for small firms but not for large firms, a surprising pattern emerges. In particular, high-beta small firms have higher excess returns than low-beta small firms in January, irrespective of whether the market return is positive or negative. This pattern is difficult to reconcile with the predictions of standard equilibrium assetpricing models, even when seasonal patterns in the betas of small firms are permitted.

Our finding that there is a positive relation between the excess return on small firms and beta, irrespective of the direction of the market in January, however, is consistent with the portfolio-rebalancing hypothesis. In particular, if there is buying pressure from individuals reinvesting the proceeds of December's taxmotivated sales and from institutional investors shifting their portfolio alloca- 
tions after year-end window dressing, then risky small stocks will outperform the market, irrespective of whether the market return is positive or negative.

Furthermore, as Haugen and Lakonishok [11] note, portfolio rebalancing effects at the turn of the year are not limited to stock returns. While we have focused exclusively on NYSE stocks, Keim and Stambaugh [15] have found that bond returns are strongly related to default risk in January but not in other months. This is consistent with portfolio rebalancing effects on asset prices.

\section{REFERENCES}

1. Marshall E. Blume. "Betas and Their Regression Tendencies." Journal of Finance 30 (June 1975), 785-96.

2. _— and Robert Stambaugh. "Biases in Computed Returns: An Application to the Size Effect." Journal of Financial Economics 12 (November 1983), 387-404.

3. K. C. Chan. "Can Tax-Loss Selling Explain the January Seasonal in Stock Returns?" Journal of Finance 41 (December 1986), 1115-28.

4. D. C. Cho and William M. Taylor. "The Seasonal Stability of the Factor Structure of Stock Returns." Journal of Finance 42 (December 1987), 1195-1211.

5. Dosoung Choi and Frank Jen. "Seasonality in Risk, Returns and Short-Term Interest Rates: Another Look at the January Effect." Unpublished SUNY-Buffalo working paper, 1988.

6. Albert Corhay, Gabriel Hawawini, and Pierre Michel. "Seasonality in the Risk-Return Relationship: Some International Evidence." Journal of Finance 42 (March 1987), 49-68.

7. Werner F. M. DeBondt and Richard Thaler. "Further Evidence on Investor Overreaction and Stock Market Seasonality.” Journal of Finance 42 (July 1987), 557-81.

8. Edward A. Dyl. "Capital Gains Taxation and Year-End Stock Market Behavior." Journal of Finance 32 (March 1977), 165-75.

9. Eugene F. Fama and James D. MacBeth. "Risk, Return, and Equilibrium: Empirical Test." Journal of Political Economy 81 (May/June 1973), 607-36.

10. Stephen P. Ferris, Robert A. Haugen, and Anil K. Makhija. "Predicting Contemporary Volume with Historic Volume at Differential Price Levels: Evidence Supporting the Disposition Effect." Journal of Finance 43 (July 1988), 677-97.

11. Robert A. Haugen and Josef Lakonishok. The Incredible January Effect. Homewood, IL: Dow Jones-Irwin, 1987.

12. Pierre Hillion and Erik R. Sirri. "The Seasonality of Market Risk." Unpublished UCLA working paper, 1987.

13. Roger G. Ibbotson. Stocks, Bonds, Bills and Inflation 1988 Yearbook. Chicago: Ibbotson Associates, 1988.

14. Donald B. Keim. "Size-Related Anomalies and Stock Return Seasonality: Further Empirical Evidence." Journal of Financial Economics 12 (June 1983), 13-32.

15. ـــ and Robert Stambaugh. "Predicting Returns in the Stock and Bond Market." Journal of Financial Economics 17 (December 1986), 357-90.

16. Craig A. MacKinley. "On Multivariate Tests of the CAPM." Journal of Financial Economics 18 (June 1987), 341-71.

17. Marc R. Reinganum. “The Anomalous Stock Market Behavior of Small Firms in January: Empirical Tests for Tax-Loss Selling Effects." Journal of Financial Economics 12 (June 1983), 89-104.

18. Jay R. Ritter. "The Buying and Selling Behavior of Individual Investors at the Turn of the Year." Journal of Finance 43 (July 1988), 701-17.

19. Richard J. Rogalski and Seha M. Tinic. "The January Size Effect: Anomaly or Risk Mismeasurement?" Financial Analysts Journal 42 (November-December 1986), 63-70.

20. Richard Roll. "Vas ist das? The Turn-of-the-Year Effect and the Return Premia of Small Firms." Journal of Portfolio Management 9 (Winter 1983), 18-28.

21. Michael S. Rozeff and William R. Kinney, Jr. "Capital Market Seasonality: The Case of Stock Returns." Journal of Financial Economics 3 (October 1976), 379-402. 
22. Seha M. Tinic and Richard R. West. "Risk and Return: January vs. the Rest of the Year." Journal of Financial Economics 13 (December 1984), 561-74.

23. —. "Risk, Return, and Equilibrium: A Revisit." Journal of Political Economy 94 (February 1986), 126-47.

24. Paul Zarowin. "Size, Seasonality, and Stock Market Overreaction." Unpublished New York University working paper, 1988.

25. Arnold Zellner. "An Efficient Method of Estimating Seemingly Unrelated Regressions and Tests for Aggregation Bias." Journal of the American Statistical Association 57 (June 1962), 348-68. 